\title{
Reclamation and Reuse of Freon in Total Petroleum Hydrocarbon Analyses
}

by

\author{
A. A. Ekechukwu \\ Westinghouse Savannah River Company \\ Savannah River Site \\ Aiken, South Carolina 29808 \\ S. F. Peterson
}

\section{DISCLAIMER}

\begin{abstract}
This report was prepared as an account of work sponsored by an agency of the United States Government. Neither the United States Government nor any agency thereof, nor any of their employees, makes any warranty, express or implied, or assumes any legal liability or responsibility for the accuracy, completeness, or usefulness of any information, apparatus, product, or process disclosed, or represents that its use would not infringe privately owned rights. Reference herein to any specific commercial product, process, or service by trade name, trademark, manufacturer, or otherwise does not necessarily constitute or imply its endorsement, recommendation, or favoring by the United States Government or any agency thereof. The views and opinions of authors expressed herein do not necessarily state or reflect those of the United States Government or any agency thereof.
\end{abstract}

\section{DOE Contract No. DE-AC09-89SR 18035}

This paper was prepared in connection with work done under the above contract number with the U.S.

Department of Energy. By acceptance of this paper, the publisher and/or recipient acknowledges the U.S. Government's right to retain a nonexclusive, royalty-free license in and to any copyright covering this paper, along with the right to reproduce and to authorize others to reproduce all or part of the copyrighted paper. 


\section{DISCLAIMER}

Portions of this document may be illegible in electronic image products. Images are produced from the best available original document. 


\section{DISCLAMMER}

This report was prepared as an account of work sponsored by an agency of the United States Government. Neither the United States Government nor any agency thereof, nor any of their employees, makes any warranty, express or implied, or assumes any legal liability or responsibility for the accuracy, completeness, or usefulness of any information, apparatus, product, or process disclosed, or represents that its use would not infringe privately owned rights. Reference herein to any. specific commercial product, process, or service by trade name, trademark, manufacturer, or otherwise does not necessarily constitute or imply its endorsement, recommendation, or favoring by the United States Government or any agency thereof. The views and opinions of authors expressed herein do not necessarily state or reflect those of the United States Government or any agency thereof.

This report has been reproduced directly from the best available copy.

Available to DOE and DOE contractors from the Office of Scientific and Technical Information, P.O. Box 62, Oak Ridge, TN 37831; prices available from (615) 576-8401.

Available to the public from the National Technical Information Service, U.S. Department of Commerce, 5285 Port Royal Road, Springfield, VA 22161. 
WSRC-RP-96-266

Keywords: Freon,

TPH,

Oil and Grease,

Waste

\section{RECLAMATION AND REUSE OF FREON IN TOTAL PETROLEUM HYDROCARBON ANALYSES (u)}

Amy A. Ekechukwu

S. F. Peterson

April 25, 1996

Authorized Derivative Classifier_echentsm 
WSRC-RP-96-266

April 25, 1996

Page 2 of 4

\section{SUMMARY}

ADS is using a commercially available solvent reclamation system to recycle $95-97 \%$ of the Freon used in total petroleum hydrocarbon analyses. ADS has further developed the commercially available solvent reclamation system to accommodate radioactive contaminated Freon. This report establishes the following:

- Validity of the method

- Success of recycling

- Effect of radionuclides in recycling radioactive contaminated Freon

\section{INTRODUCTION}

The standard analysis method for determining total petroleum hydrocarbons (commonly known as oil and grease determination) involves solvent extraction of the hydrocarbons using Freon followed by quantitation using infrared detection. This has been the method of choice because it is simple, rugged, inexpensive, and applicable to both solid and liquid samples and to radioactive samples. Due to its deleterious effect on the ozone layer; the use of Freon and other chloro-fluorocarbons (CFCs) has been greatly restricted. Freon has become very expensive (800\$/liter) and will soon be unavailable entirely.

Several methods have been proposed to replace the Freon extraction method. These methods include solid-phase extraction, solvent extraction, and supercritical fluid extraction all of which use gravimetric determination or infrared analysis of the extracted hydrocarbons. These methods are not as precise or as sensitive as the Freon extraction method, and a larger amount of sample is therefore required due to the decreased sensitivity. The solid phase extraction method cannot accomodate solid samples. Supercritical fluid extraction requires expensive instrumentation $(\$ 100,000)$ and facility services (high pressure ultrapure carbon dioxide) and the instrumentation requires a significant amount of bench top and hood space, which makes the method not feasible for radioactive sample analysis. All replacement methods would require procurement of new equipment and retraining of analysts.

ADS opted to keep the existing Freon method and recycle the solvent. An inexpensive solvent reclamation system was procured to reclaim the spent Freon. This reclaimer removes hydrocarbons from the Freon solvent by passage through an activated carbon bed. The operation is simple - spent Freon is poured into the top of the instrument and clean Freon is obtained from a tap at the bottom. The hydrocarbon content of the reclaimed Freon is measured to ensure its purity.

\section{EXPERIMENTAL}

\section{Principle of the Method and Experimental Details}

The spent Freon is collected and then passed in $500 \mathrm{~mL}$ batches through an Horiba Solvent Reclaimer. This unit consists of an activated carbon bed through which the spent solvent is passed. Hydrocarbons are trapped by the carbon bed. The bed has a capacity of 5 grams of hydrocarbon. This bed is replaced routinely every 6 months or if the measured hydrocarbon content of the reclaimed Freon is above $0.2 \mathrm{ppm}$ (twice the minimum detection limit of the analyzer). The fresh carbon bed must be conditioned with approximately $500 \mathrm{~mL}$ of Freon before the system can be used to reclaim spent solvent. The Freon used in this priming is also recycled. 


\section{Method Validation}

The infrared absorbance of this reclaimed solvent is measured in the oil content analyzer. The content must be less than $0.2 \mathrm{ppm}$ hydrocarbon. If the measured oil content exceeds this value, this is an indication that the hydrocarbon content of the carbon bed is near capacity and the bed is changed out. The accuracy and precision of measurements using fresh and reclaimed solvent are the same since the Freon is tested for purity before use.

\section{DISCUSSION}

\section{Separation Efficiency}

The carbon bed traps organic material which is soluble in Freon. Freon containing up to $0.1 \%$ by volume of hydrocarbons $(1000 \mathrm{ppm})$ has been introduced into the unit and essentially all the hydrocarbons have been removed. The separation is effectively $100 \%$ provided that the capacity of the bed has not been exceeded. The batches of Freon introduced into the unit for recycle are generally less than $25 \mathrm{ppm}$ hydrocarbon. This is because the linear calibration limit of the unit is $50 \mathrm{ppm}$. Samples which contain greater than this amount are diluted. There is usually three times the amount of Freon used to rinse and zero the instrument between samples.

\section{Recovery Yield}

Freon evaporates very quickly. The waste from the oil content analyzer is kept in a closed container until enough is accumulated for recycle. When the Freon contacts the carbon bed, some heat is given off due to interaction with the carbon. This heat causes a small volume of the Freon to evaporate. In addition, some evaporative loss is experienced on collection. Approximately 95 to $97 \%$ of the volume of Freon introduced into the carbon bed unit is recovered.

\section{Effect of Radionuclides}

The effect of radionuclides was of concern when recycling Freon which had been contacted with radioactive samples. When a radioactive sample was extracted with Freon, the radionuclides present in that sample could follow one of three paths: the radionuclides could remain in the aqueous portion of the sample; the radionuclides could be extracted with the hydrocarbons into the Freon and remain in the Freon when passed through the carbon bed; the radionuclides could be extracted into the Freon and be trapped by the carbon bed. Determining the fate of the radionuclides was essential to ensure that radioactive material was not being concentrated in either the Freon or the carbon bed.

Since the radioisotopes present in the waste are inorganic it was believed that they would not be extracted into the Freon. This proved to be true for strontium, cesium, and plutonium isotopes, however a measurable amount of tritium was extracted from aqueous samples into the Freon. This transfer was probably effected via hydrogen ion exchange with organic species present in the sample. This tritium activity remained in the Freon after passage through the carbon bed. Washing the contaminated Freon with an equal volume of deionized water effectively removed all the tritium activity so that the Freon could be passed through the carbon bed for recycle. Reclaimed Freon is analyzed for radioactive material to ensure that no build-up of radioactive material is occurring. 
WSRC-RP-96-266

April 25, 1996

Page 4 of 4

\section{CONCLUSION AND PATH FORWARD}

Using the carbon bed unit, 95-97\% of Freon can be reclaimed and reused. ADS has modified the reclamation method to enable the recycle of Freon used in radioactive sample analysis. ADS is currently developing a sealed reclamation unit which will decrease the loss of Freon due to evaporation and allow continuous rather than batch solvent recycle. 
WSRC-RP-96-266

April 25, 1996

TO:

A.L. Blancett, 773-A

FROM:

A.A. Ekechukwu, 773-A

S.F. Peterson, 773-41A

CC: W.R. Wilmarth, 773-43A

J.E. Young, 773-A

S.M. Dyer, 704-28S

H.F. Kelly, 773-A

M.A. Polochko, 773-A

SRTC Records (4)

M.A. Schilb, 772-F

P.F. Cloessner, 773-A

J.C. Griffin, 773-A 